\title{
Crosstalk between transcription factors in regulation of the human glutathione S-transferase $P 1$ gene expression in Me45 melanoma cells
}

\author{
A. M. Slonchak, A. Chwieduk ${ }^{1}$, J. Rzeszowska-Wolny ${ }^{1}$, M. Yu. Obolenskaya \\ Institute of Molecular Biology and Genetics NAS of Ukraine \\ 150, Zabolotnogo str., Kyiv Ukraine, 03680 \\ ${ }^{1}$ M. Sklodowska-Curie Memorial Cancer Center and Institute of Oncology in Gliwice \\ Wybrzezhe Armiji Krajowej 15, 44-101, Gliwice, Poland \\ elephass@gmail.com
}

\begin{abstract}
Aim. The human GSTP1 is a major enzyme of phase II detoxification in the most cell types. Aberrant expression of GSTP1 is associated with carcinogenesis and development of multidrug resistance. The GSTP1 gene expression is regulated at multiple levels including transcriptional, post-transcriptional and post-translational. We concentrated our attention on the transcriptional level of regulation. Methods. Transient transfection of Me45 melanoma cells with constructs containing the luciferase gene under the control of complete and truncated GSTP1 promoter was utilized to identify a role of different promoter regions in regulation of the gene transcription in Me45 cells. To identify the transcription factors, interacting with the GSTP1 promoter sites, the competitive EMSA and super shift assay were applied. Results. GSTP1 transcription in Me 45 cells is positively regulated by binding $N F-\kappa B$ to the cognate site and ERß in complex with unknown protein to the ARE site; the complex of ER $\beta$ with c-Fos negatively regulates the gene expression via CRE site. The interaction of c-Fos/ER $\beta$ with GSTP1 CRE site and indirect interaction of ERß with GSTP1 ARE were identified. Conclusions. The positive regulation of the human GSTP1 gene in Me45 melanoma cells is exerted via NF- $\mathrm{KB}$ and ARE sites and the negative one via CRE site of the promoter. ERß is indirectly involved in the regulation of GSTP1 transcription. It is bound via c-Fos with CRE site and via unknown protein with ARE site.
\end{abstract}

Keywords: glutathione S-transferase, promoter, transcription factors, $N F-\kappa B$, estrogen receptor, melanoma, transcription regulation.

Introduction. Glutathione S-transferases comprise a multigene superfamily of enzymes that catalyze the conjugation of electrophilic toxic compounds with glutathione, playing a key role in phase II of detoxification [1]. The human GSTP1 isoform is a major GST isoenzyme in most cell types, except hepatocytes [2]. Besides its typical role in detoxification it possesses other functions, including a ligandin function [3], modulation of signaling pathways [4], conjugation and transport of steroid hormones [5], and

(C) Institute of Molecular Biology and Genetics NAS of Ukraine, 2009 participates in dinitrosyl-diglutathionyl-iron complex storage and metabolism [6]. Aberrant expression of GSTP1 is associated with carcinogenesis and development of multidrug resistance (MDR).

The regulation of the GSTPI gene expression is in the focus of researchers and clinicians interests because the stimulation of GSTP1 expression is expected to be used as a preventive approach against cancer while its down-regulation is in need to counteract the development of MDR. The GSTP1 gene expression is regulated at multiple levels including transcriptional, post-transcriptional and post-translational [7]. We concentrate our attention on the transcriptional level of regulation. 
Despite the vast literature devoted to GSTP1 enzyme the functional characteristics of responsive elements in gene promoter and tissue-specific peculiarities of their regulation are poorly understood. Moreover the previous investigations of molecular mechanisms involved in the GSTP1 regulation were focused mainly on breast cancer, leukemia and prostate cancer cells. In present research we performed a functional analysis of GSTP1 promoter in human melanoma cells Me45. We utilized truncated promoter constructions to compare the functional role of different cis-acting promoter elements and identified transcription factors binding the responsive elements by competitive EMSA (electrophoretic mobility shift assay) and supershift assay.

Matherials and methods. Cell culture. Human melanona cell line Me45 was obtained from Polish Cell Bank and propagated in DMEM/F12 medium ( «Sigma», USA) supplemented with $588 \mu \mathrm{g} / \mathrm{ml}$ L-glutamine, $0.16 \% \mathrm{NaHCO}_{3}, 10 \%$ heat inactivated fetal calf serum («Gibco», USA) and $100 \mu \mathrm{g} / \mathrm{ml}$ gentamicine. Cells were grown at $37{ }^{\circ} \mathrm{C}$ in an atmosphere of $95 \%$ air and $5 \% \mathrm{CO}_{2}$.

Promoter deletion constructs. Fragments of GSTP1 gene promoter were prepared by PCR. The oligonucleotide 5'-ACTCACTGGTGGCGAAGACT-3' (position +15 to +35 ) was used as the downstream primer for all constructions. Each of the following oligonucleotides was used as upstream primers to amplify promoter fragments: 5'-CATAAACACCA- ACCTCTTCCCC-3' (position -1379 to -1357) for $p$ GSTP1415, 5'-ATAGCCTAAGGCACAGCCAC-3' (position -1162 to -1142) for $p G S T P 1197,5^{\prime}$-TTTCCTTTCCTCTAAGCGGC-3' (position -405 to -385) for $p$ GSTP440, 5'-AGTCCGCG GGACCCTCCAGA-3' (position -105 to -85) for pGSTP140 and 5'-AGAGCGGCCGGCGCCGTGAC$3^{\prime}$ (position -85 to -64 ) for $p G S T P 120$. The amplified products were subcloned into pCR $^{\circledR} 2.1-\mathrm{TOPO}^{\circledR}$ vector («Invitrogen», USA). The recombinant plasmids were sequenced and the orientation of inserts was determined. Plasmids with directly oriented inserts were submitted to digestion with KpnI and XhoI. Excised inserts were religated into $p G L 3$-basic (plasmid with Glo ${ }^{\mathrm{TM}} \underline{\text { Lu}}$ - ciferase 3 basic) plasmid ( Promega», USA). Resulted constructs were named $p G S T P X$, were $X$ corresponds to the length of the inserted promoter fragment and GSTP is the gene name. Sequences of relevant regions of the final constructs were confirmed by sequencing in both directions in Oligo.pl DNA IBB PAN Service (Poland).

Transient transfection assay. Me45 cells were grown in 24-well plates to $60 \%$ confluence and transfected with $500 \mathrm{ng}$ of $p G S T P$ together with $25 \mathrm{ng}$ of $p R L-T K$ (plasmid with Renilla Luciferase and Thymidine kinase Promoter) plasmid («Promega», USA) per well using Lipofectamine ${ }^{\mathrm{TM}}$ LTX and PLUS ${ }^{\mathrm{TM}}$ reagents («Invitrogen», USA). After $20 \mathrm{~h}$ the firefly and renilla luciferase activities were assessed using Dual Luciferase ${ }^{\circledR}$ Reporter Assay System («Promega», USA).

Electrophoretic mobility shift assay. Nuclear extracts from Me45 cells were prepared by modified method of Dignam et al. [8]. The following oligonucleotides and their complementary sequences were used as probes in EMSA experiment: ARE (ㅅntioxidant Response Element of human GSTP1 promoter) 5'-CGCCGTGACTCAGCACTGGG-3', NF-кBlike (Nuclear Factor $\mathrm{kB}$-like site of human GSTP1 promoter) 5'-TCCGCGGGACCCTCCAGAAG-3', NF-кB (Nuclear Factor $\underline{\mathrm{KB}}$ site of human GSTP1 promoter) 5'-CTTAGGGAATTTCCCCCCGC-3', CRE (Cyclic

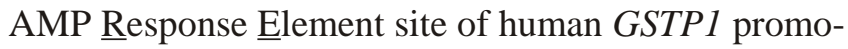
ter) 5'-GAGACTACGTCATAAAATAA-3', GATA (GATA-1 binding site of human GSTP1 promoter) 5'-GAGATCAATATCTAGAAATAA-3'. Probes (10 pmoles) were labeled with 20 pmoles $\left[\gamma^{32} \mathrm{P}\right]$-ATP $6000 \mathrm{Ci} / \mathrm{mmole}$ («Hartmann Analytic», Deutschland) by polynucleotide kinase («Roche», Switzerland).

Unincorporated nucleotides were removed by gel-filtration through Bio-gel ${ }^{\circledR}$ P-30 («Bio-Rad», USA). Electrophoretic mobility shift assay was performed using Electropforetic mobility shift assay kit («Promega»). Consensus oligonucleotides for AP-1

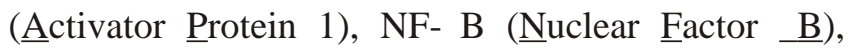
CREB (Cyclic AMP Response Element Binding

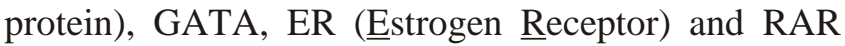
(Retinoic $\underline{\text { Acid }}$ Receptor), antibodies against human c-Jun, c-Fos, MafF/G/K, ER $\beta$, Nrf3 (Nuclear erythroid 2 p45 related factor $\underline{3}$ ), NF- $\kappa B$ p50, NF- $\kappa B$ p65 and normal rabbit IgG were from «Santa Cruz Biotechnology» (USA).

Results and discussion. Functional analysis of the GSTP1 promoter regions in Me45 cells. The structure of GSTP1 promoter is summarized in fig. 1. To identify 


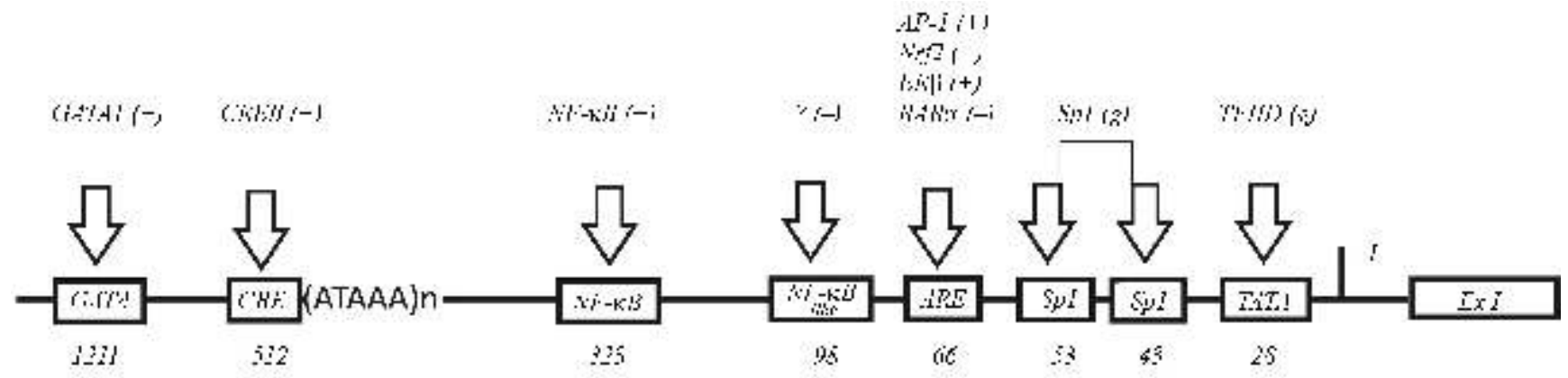

Fig. 1. Structure of the human GSTP1 gene 5'-regulatory region and potential transcription factors interacting with it [9-13]: «+»-positive regulation; «-»- negative regulation; $g$ - general transcription factors

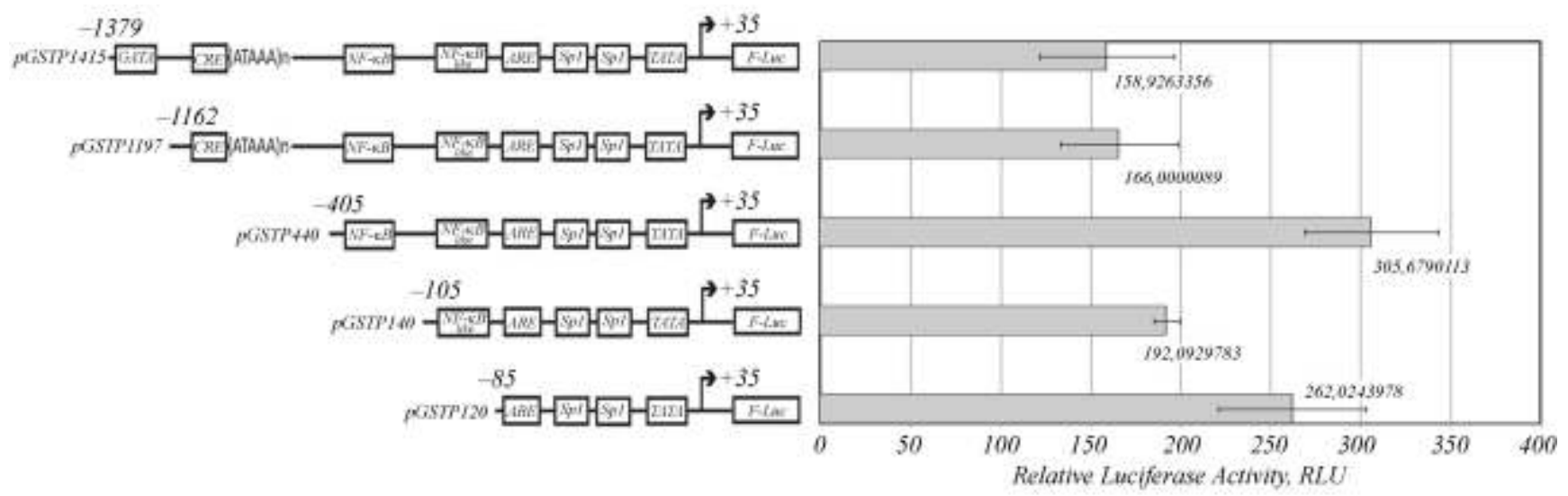

Fig. 2. Schematic representation of the reporter constructs and their activities in transfected Me45 cells. Relative luciferase activity was calculated as a ratio of firefly to renilla luciferase light emission. Cells cotransfected with $p G L 3$-basic and $p R L-T K$ vectors were as a negative control

the role of GSTP1 promoter regions in regulation of GSTP1 transcription in Me45 cells we utilized transient transfection assay with reporter constructs containing complete or truncated GSTP1 promoter fused to the firefly luciferase gene. For this purpose we designed the reporter constructs each lacking the DNA fragment with one transcription factor binding site (fig. 2). The diagram in fig. 2 represents relative firefly luciferase activities in lysates of Me45 cells transfected with reporter constructs. Each bar in the graph represents the average of 3 independent experiments with triplications in each.

Transfection of the largest vector ( $p$ GSTP1415) containing the GSTP1 promoter fragment from -1379 to +35 resulted in relatively high level of $f$-luc gene expression in Me45 cells. Deletion of the GSTP1flanking region between -1379 and -1162 , containing
GATA-binding site, did not influence significantly the expression of the reporter gene. Deletion of the region from -1162 to -405 , which contains CRE and ATAAA-repeat, resulted in increase of f-luc expression approximately 1.8 -fold in comparison with previous construct. Further deletion of the region from -405 to -105 , containing NF- $\mathrm{KB}$ site, reduced the reporter gene expression 1.6-fold. Deletion of the region from -105 to -85 , known as an NF- $\mathrm{kB}$-like element, resulted in 1.5-fold increase of f-luc expression.

Thereby, the results of the transient transfection experiments suggest the presence of the negative regulatory elements located in the regions from -1162 to -405 and from -105 to -85 . Also it provided the evidence for the presence of the strong positive regulatory element located from -405 to -105 . The similar role of promoter sequences in the regulation of 


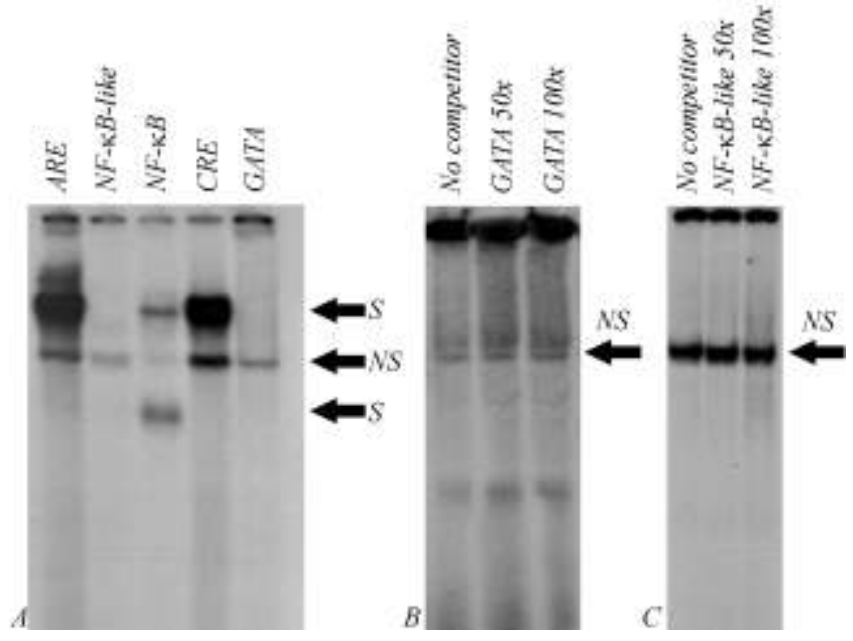

Fig. 3. In vitro binding of Me45 nuclear proteins to GSTP1 promoter sites: $A$ - electrophoretic mobility shift assay, demonstrating the ability of Me45 nuclear proteins to form complexes with ARE, NF$\kappa \mathrm{B}, \mathrm{NF}-\kappa \mathrm{B}-\mathrm{like}, \mathrm{CRE}$ and GATA sites; $B$ - results of competitive EMSA demonstrating, that protein binding to NF- $\mathrm{kB}$-like site is nonspecific; $C$ - results of competitive EMSA demonstrating, that protein binding to GATA site is nonspecific; $S$ - specific complex; $N S$ - nonspecific complex

GSTP1 gene transcription was identified by Jhaveri and Morrow [14] for breast cancer cells.

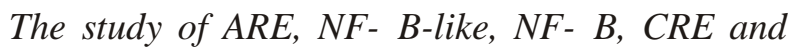
GATA binding sites interactions with nuclear proteins from Me 45 cells. For identification of the transcription factors interacting with the GSTP1 promoter the electrophoretic mobility shift assay (EMSA) was applied. The ability of $20 \mathrm{bp}$ promoter fragments, containing ARE, NF- $\kappa B$-like, NF- $\kappa B, C R E$ and GATA sites to bind nuclear proteins from Me45 cells was examined in this experiment. Fig. 3 shows that all oligonucleotides form complexes with nuclear proteins. Specificity of the protein binding was assessed in a competition experiment, in which nuclear proteins were preincubated in 50- and 100-fold molar excess of unlabeled probe. In this experiment we determined, that ARE, NF-KB and CRE sites specifically bind nuclear proteins while NF- $\mathrm{KB}$-like and GATA sites do not. One band observed in all elrctrophoregrams was non-specific because it was not eliminated in competitive experiments (fig. 3, $A, B, C$ ).

Surprisingly, we did not find any proteins interacting with NF-kB-like element which was identified as a negative regulator of GSTP1 transcription in the transient transfection experiment. We suppose that the «negative» role of the NF- B-like element in GSTP1 transcription may be connected with the presence of palindrome GGGACCCtc in the region that may hinder an enchanceosome formation.

The region spanning nucleotides from -85 to +35 which is shown to be able to support the transcription of the reporter gene in Me45 cell at the level even higher than the full-length promoter is known to be a minimal promoter essential for the GSTP1 gene expression. This minimal promoter region contains ARE site which interacts with different transcription factors - AP-1 [15], Nrf2 [16], ER $\beta$ [17] and RAR $\alpha$ [18], depending on cell type. To identify the transcription factors acting on this site in Me45 cells we performed competitive EMSA with consensus oligos for AP-1, Maf (the DNA-binding component of Nrf2), ER $\beta$ and RAR $\alpha$ and supershift assay with antibodies for these transcription factors. Consistent with results shown in fig. 4 , $A$, a 50- and 100-fold molar excess of unlabeled consensus oligonucleotides for AP-1, Maf, estrogen receptor beta $(E R \beta)$ and retinoic acid receptor (RAR) were not able to compete for the nuclear proteins binding to the ARE site. It means that AP-1, Maf, ER $\beta$ and RAR $\alpha$ do not interact with ARE site through their DNA-binding domains. To clarify these results the supershift experiment with polyclonal antibodies to c-Jun (cross-reactive to JunB and JunD), c-Fos (cross-reactive to FosB, Fra1 and Fra2), MafF/G/K, ER $\beta$ and Nrf3 (the placenta-specific homolog of Nrf2) was performed. As indicated in fig. 4, $A$, neither transcription factors Jun, Fos nor Maf and Nrf3 prevent the formation of specific complex of ARE site with a nuclear protein. Only ER $\beta$ antibody prevents the whole complex formation resulting in appearance of a new complex with higher electrophoretic mobility. This result clearly indicates that in Me45 nuclear extracts ER $\beta$ binds to the GSTP1 ARE site through another yet unknown protein and DNA-binding domain of ER $\beta$ is not involved in these interactions.

The region of GSTP1 promoter from -405 to -105 contains NF- $\mathrm{KB}$ site and positively regulates the reporter gene transcription in Me45 cells. This site binds NF- $\mathrm{KB}$ in K562 leukemia cells and mediates the gene induction by TNF $\alpha$ [11]. The results of the GSTP1 promoter NF- $\mathrm{\kappa B}$ site binding assay are summarized in fig. $4, B$. Two specific bands were 

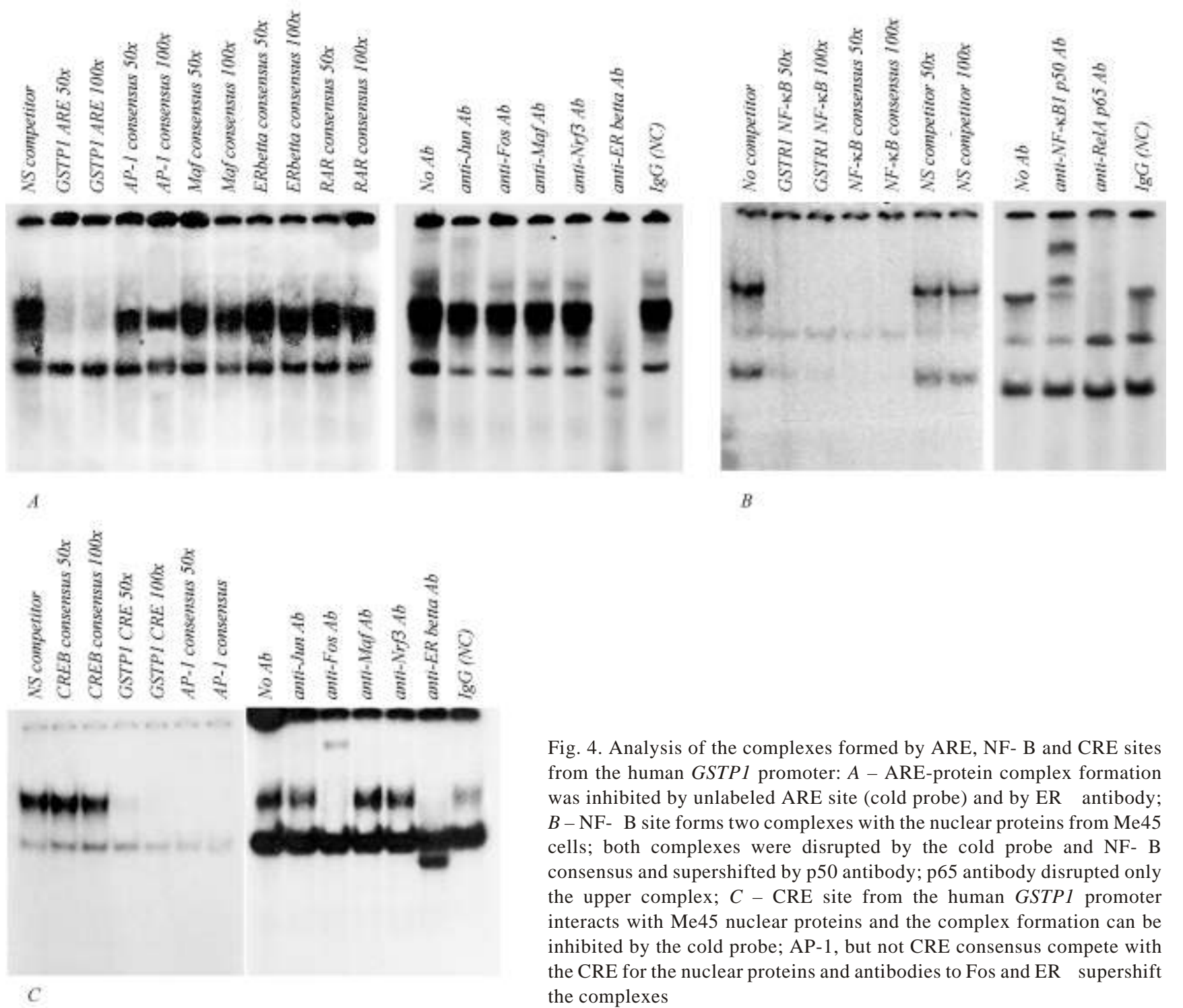

Fig. 4. Analysis of the complexes formed by ARE, NF- B and CRE sites from the human GSTP1 promoter: A - ARE-protein complex formation was inhibited by unlabeled ARE site (cold probe) and by ER $\beta$ antibody; $B-\mathrm{NF}-\mathrm{\kappa B}$ site forms two complexes with the nuclear proteins from Me45 cells; both complexes were disrupted by the cold probe and NF- $\mathrm{KB}$ consensus and supershifted by $\mathrm{p} 50$ antibody; 65 antibody disrupted only the upper complex; $C$ - CRE site from the human GSTP1 promoter interacts with Me45 nuclear proteins and the complex formation can be inhibited by the cold probe; AP-1, but not CRE consensus compete with the CRE for the nuclear proteins and antibodies to Fos and ER $\beta$ supershift the complexes

observed in the reaction of genuine NF- $\mathrm{KB}$ site containing oligo with nuclear extract. The unlabeled $\mathrm{NF}-\mathrm{kB}$ consensus was able to efficiently compete for the nuclear proteins from both specific complexes leading to suggestion that NF- $\kappa \mathrm{B}$ binds to GSTP1 $\mathrm{NF}-\kappa \mathrm{B}$ site in this cell line. To clarify the matter, nuclear extract was incubated with polyclonal antibodies to $\mathrm{p} 50$ and $\mathrm{p} 65$ subunits of NF- $\mathrm{\kappa B}$ before the probe was added to the EMSA reaction. In the supershift assay of NF- $\mathrm{KB}$ site two new bands were observed after the incubation with p50 antibody - one originated from the lower and one from the upper complex, providing the evidence that both complexes contain $\mathrm{p} 50$. The upper complex of nuclear proteins and
$\mathrm{NF}-\mathrm{\kappa B}$ site contains the $\mathrm{p} 50 / \mathrm{p} 65$ heterodimer, while the lower complex observed in binding reaction is the $\mathrm{p} 50 / \mathrm{p} 50$. These data together with the results of transient transfection assay strongly suggest that NF$\kappa \mathrm{B}$ interacts with the human GSTP1 NF- $\kappa \mathrm{B}$ site and up-regulates gene transcription in Me45 cells.

The negative regulatory element $-1162 \ldots-404$ contains a CRE site and ATAAA-repeated sequence. It was previously reported that CRE site of GSTP1 mediates gene response to cAMP by interacting with CREB in Calu-6 lung cancer cells [19]. Competitive EMSA was also conducted to determine which protein is a part of the DNA-protein complex formed by CRE site in Me45. Regarding the ability of CRE sites in 
different genes to interact with CREB [19] and AP-1[20] proteins, consensus oligonucleotides for both transcription factors were utilized in the competitive EMSA. A representative autoradiograph in fig. 4, $C$, shows, that CREB consensus oligonucleotide could not compete with GSTPI promoter CRE for protein binding, however genuine oligonucleotide CRE and AP-1 consensus competed successfully. This suggests that CRE site forms the complex with AP-1 in Me45 cells. The supershift experiment with antibodies against the transcription factors known to interact directly or indirectly with CREs of other genes was performed to verify the results. Antibodies to c-Jun (cross-reactive to JunB and JunD), c-Fos (cross-reactive to FosB, Fra1 and Fra2), MafF/G/K, ER $\beta$ and Nrf3 were utilized in this assay. The supershifted bands were observed after the incubation of nuclear extracts with Fos and ER $\beta$ antibodies. The supershift analysis indicates that ER $\beta$ together with Fos protein interacts with the human GSTP1 CRE in Me45 cells and this interaction has a negative regulatory effect.

The phenomenon that protein binding sites can be shared between different transcription factors is called a transcription factor crosstalk [20]. It can be realized by interaction of a «noncanonical» transcription factor directly with a DNA sequence which has a partial homology to the binding sites of this and another transcription factors [20] or by protein-protein interactions of «noncanonical» transcription factor with a «genuine» protein bound to its recognition site. In case of the human GSTP1 promoter both types of crosstalk are present - noncanonical c-Fos together with ER $\beta$ crosstalks with CREB at CRE site and ER $\beta$ together with an unknown protein crosstalks with AP-1 at ARE site. In both cases CREB and Fos/Jun has an opposite effect on gene transcription. In case of the GSTP1 promoter this negative effect is seems to be potentiated by ER $\beta$ binding which is known to repress Fos-driven transcription [21]. In the present finding we identified ER $\beta$ indirectly interacting with two promoter elements - CRE and ARE sites. It evidences for the importance of this protein for the formation of the enchanceosome on GSTP1 promoter.

The ER signaling mechanisms discussed until now provide an explanation for the regulation of genes lacking estrogen response element and requiring a second DNA-binding transcription factor to mediate ER association with the DNA. ER $\alpha$ and ER $\beta$ have been shown to act in opposite ways at Fos/Jun-binding sites. In the presence of $\mathrm{E} 2 \mathrm{ER} \alpha$ activates transcription via its AF-1 and AF-2 transactivating domains while ER $\beta$-E2 which lacks a functional AF-1 inhibits the Fos/Jundependent transcription [22]. We suggest that ER $\beta$ exerts the similar inhibitory effect at CRE site of GSTP1 promoter. The role of ER $\beta$ associated with an unknown protein at ARE site is different and may activate transcription. The dual function of ER $\beta$ in regulation of different promoter elements may be considered in context of enchanceosome formation.

Conclusions. In the present research the transcriptional mechanisms controlling the basal level of GSTP1 expression in Me45 cells have been analyzed for the first time. The obtained data indicate that the GSTP1 transcription in this cell type is positively regulated by binding of NF- $\kappa B$ to -323 site and $E R \beta$ in complex with unknown protein binding to the ARE site; the complex of ER $\beta$ with c-Fos at CRE site negatively regulates the gene expression. The interaction of c-Fos/ER $\beta$ with GSTP1 CRE site and indirect interaction of ER with GSTPI ARE site have been discovered.

The regulation of GSTP1 transcription in Me45 melanoma cells has been examined in details also for the first time. Several transcription factors $-\mathrm{NF}-\kappa \mathrm{B}$ in p50/p50 homodimer and p50/p65 heterodimer, ER $\beta$ and c-Fos regulate GSTP1 transcription in these cells. Positive regulation is exerted via NF- $\mathrm{KB}$ and ARE sites and negative via CRE site. ER $\beta$ is indirectly involved in regulation of GSTP1 transcription. It is bound via c-Fos with CRE site and via unknown protein with ARE site.

Acknowledgement. The experimental part of the work was carried out in the Institute of Oncology in Gliwice and was financed by the Polish Ministry of Education and Science, grant number N 401157 32/3043.

А. М. Слончак, А. Кведук, Й. Жешовска-Вольни,

М. Ю. Оболенська

Переговори між транскрипційними факторами у регуляції експресії гена P1 глутатіон-S-трансферази людини у клітинах меланоми Ме45 
Резюме

Мета.Глутатіон-S-трансфераза (GTaза) людини є головним ферментом II фази детоксикації у більшості типів клітин. Зміна рівня експресії ї̈ гена пов'язана з канцерогенезом $і$ формуванням численної лікарської стійкості. Експресія GTазиP1 регулюється на транскрипційному, посттранскрипційному та посттрансляційному рівнях. У даній роботі ми зосередилися на транскрипційній регуляції гена. Методи. Трансфекцію клітин меланоми Ме45 конструкціями, які містять ген люциферази під контролем повного або вкороченого промотора GTазиPI, використано для встановлення ролі різних ділянок промотора в регуляції транскрипиії гена GTази P1 у клітинах Ме45. Щоб визначити транскрипційні фактори, які взаємодіють з промотором гена GTазиP 1, виявляли зміни електрофоретичної рухливості ДНК-білкових комплексів за присутності антитіл і конкурентних олігонуклеотидів. Результати. Транскрипція гена GTазиP1 у клитинах Me45 позитивно регулюеться через зв'язування $N F-\kappa B$ із сайтом -323 та за рахунок зв'язування ERß у комплексі з невідомим білком - 3 ARE-сайтом; комплекс ERß з с-Fos негативно регулює експресію гена. Встановлено також пряму взаємодію c-Fos/ERß із сайтом CRE гена GTaзиP1 i непряму - ERß із сайтом ARE. Висновки. Позитивна регуляція гена GTазиP1 людини в клітинах меланоми Me45 здійснюється через NF-кB i ARE-сайти, а негативначерез CRE-сайт промотора. ERß опосередковано бере участь у регуляцї̈ транскрипцї̈ GTaзиP1: через с-Fos він зв'язується 3 CRE-сайтом і через невідомий білок-з ARE-сайтом.

Ключові слова: глутатіон-S-трансфераза, промотор, транскрипційні фактори, $N F-\kappa B$, естрагеновий рецептор, меланома, регуляція транскрипції.

А. М. Слончак, А. Кведук, Й. Жешовска-Вольны, М. Ю. Оболенская

Переговоры между транскрипционными факторами в регуляции экспрессии гена P1 глутатион-S-трансферазы человека в клетках меланомы Me45

Резюме

Цель. Глутатион-S-трансфераза (GTаза) человека является главным ферментом II фазы детоксикации в большинстве типов клеток. Изменение уровня экспрессии ее гена связано с каниерогенезом и формированием множественной лекарственной устойчивости. Экспрессия GTазыP1 регулируется на транскрипционном, посттранскрипционном и посттрансляционном уровнях. В данной работе мы сосредоточились на транскрипционной регуляции гена. Методы. Трансфекция клеток меланомы Ме45 конструкциями, содержащими ген люциферазы под контролем полного или укороченного промотора GTaзыP1, использована для выяснения роли разных участков промотора в регуляции транскрипции гена GTазы P1 в клетках Ме45. Чтобы выявить транскрипционные факторы, взаимодействующие с промотором гена GTaзыP1, определяли изменения электрофоретической подвижности ДНК-белковых комплексов в присутствии антител и конкурентных олигонуклеотидов. Результаты. Транскрипция гена GTазыP1 в клетках Me45 позитивно регулируется через связывание $N F-\kappa B$ с сайтом-323 и через связывание ERß в комплексе с неизвесным белком - c ARE-сайтом; комплекс ERß c c-Fos негативно регулирует экспрессию гена. Установлено также прямое взаимодействие с-Fos/ERß с сайтом CRE гена GTaзыP1 и непрямое - ERß $\beta$ с сайтом ARE. Выводы. Позитивная регуляция гена GTaзыP1 человека в клетках меланомы Ме45 осуществляется через NF$\kappa B$ и ARE-cайты, а негативная - через CRE-сайт промотора. ERß опосредованно участвует в регуляции транскрипции GTaзыP1: через c-Fos он связывается с CRE-сайтом и через неизвестный белок-с ARE-сайтом.

Ключевые слова: глутатион-S-трансфераза, промотор, транскрипционные факторы, $N F-\kappa B$, эстрагеновый рецептор, меланома, регуляция транскрипции.

\section{REFERENCES}

1. Hayes J. D., Flanagan J. U., Jowsey I. R. Glutathione transferases // Annu. Rev. Pharmacol. Toxicol.-2005.-45.P. 51-88.

2. Moscow J. A., Fairchild C. R., Madden M. J., Ransom D. T., Wieand H. S., O'Brien E. E., Poplack D. G., Cossman J., Myers C. E., Cowan K. H. Expression of anionic glutathione$\mathrm{S}$-transferase and P-glycoprotein genes in human tissues and tumors // Cancer Res.-1989.-49, N 6.-P. 1422-1428.

3. Oakley A. J., Lo B. M., Nuccetelli M., Mazzetti A. P., Parker $M$. W. The ligandin (non-substrate) binding site of human Pi class glutathione transferase is located in the electrophile binding site (H-site) // J. Mol. Biol.-1999.-291, N 4.-P. 913926.

4. Zhao X., Fan Y., Shen J., Wu Y., Yin Z. Human glutathione S-transferase P1 suppresses MEKK1-mediated apoptosis by regulating MEKK1 kinase activity in HEK293 cells // Mol. Cells.-2006.-21, N 3.-P. 395-400.

5. Paakki P., Kirkinen P., Helin H., Pelkonen O., Raunio H., Pasanen M. Antepartum glucocorticoid therapy suppresses human placental xenobiotic and steroid metabolizing enzymes // Placenta.-2000.-21, N 2-3.-P. 241-246.

6. Turella P., Pedersen J. Z., Caccuri A. M., De M. F., Mastroberardino P., Lo B. M., Federici G., Ricci G. Glutathione transferase superfamily behaves like storage proteins for dinitrosyl-diglutathionyl-iron complex in heterogeneous systems // J. Biol. Chem.-2003.-278, N 43.-P. 42294-42299.

7. Moffat G. J., McLaren A. W., Wolf C. R. Transcriptional and post-transcriptional mechanisms can regulate cell-specific expression of the human Pi-class glutathione S-transferase gene // Biochem. J.-1997.-324, pt 1.-P. 91-95.

8. Dignam J. D., Lebovitz R. M., Roeder R. G. Accurate transcription initiation by RNA polymerase II in a soluble extract from isolated mammalian nuclei // Nucl. Acids. Res.-1983.11, N 5.-P. 1475-1489.

9. Cowell I. G., Dixon K. H., Pemble S. E., Ketterer B., Taylor J. $B$. The structure of the human glutathione S-transferase $\mathrm{Pi}$ gene // Biochem. J.-1988.-255, N 1.-P. 79-83.

10. Xia C. L., Cowell I. G., Dixon K. H., Pemble S. E., Ketterer $B$, Taylor J. B. Glutathione transferase pi its minimal promoter and downstream cis-acting element // Biochem. Biophys. Res. Communs.-1991.-176, N 1.-P. 233-240.

11. Morceau F., Duvoix A., Delhalle S., Schnekenburger M., Dicato $M$., Diederich $M$. Regulation of glutathione S-transferase P1-1 gene expression by NF-kappaB in tumor necrosis factor alpha-treated K562 leukemia cells // Biochem. Pharmacol.-2004.-67, N 7.-P. 1227-1238.

12. Schnekenburger M., Morceau F., Duvoix A., Delhalle S., Trentesaux C., Dicato M., Diederich M. Expression of glutathione S-transferase P1-1 in differentiating K562: role of 
GATA-1 // Biochem. Biophys. Res. Communs.-2003.-311, N 4.-P. 815-821.

13. Moffat G. J., McLaren A. W., Wolf C. R. Sp1-mediated transcriptional activation of the human Pi class glutathione S-transferase promoter // J. Biol. Chem.-1996.-271, N 2.-P. 10541060.

14. Jhaveri M. S., Morrow C. S. Contribution of proximal promoter elements to the regulation of basal and differential glutathione S-transferase P1 gene expression in human breast cancer cells // Biochim. Biophys. Acta.-1998.-1396, N 2.P. 179-190

15. Duvoix A., Schmitz M., Schnekenburger M., Dicato M., Morceau F., Galteau M. M., Diederich M. Transcriptional regulation of glutathione S-transferase P1-1 in human leukemia // Biofactors.-2003.-17, N 1-4.-P. 131-138.

16. Nishinaka T., Ichijo Y., Ito M., Kimura M., Katsuyama M., Iwata K., Miura T., Terada T., Yabe-Nishimura C. Curcumin activates human glutathione $\mathrm{S}$-transferase $\mathrm{P} 1$ expression through antioxidant response element // Toxicol. Lett.2007.-170, N 3.-P. 238-247.

17. Montano M. M., Deng H., Liu M., Sun X., Singal R. Transcriptional regulation by the estrogen receptor of antioxidative stress enzymes and its functional implications // Oncogene.2004.-23, N 14.-P. 2442-2453.
18. Xia C., Hu J., Ketterer B., Taylor J. B. The organization of the human GSTP1-1 gene promoter and its response to retinoic acid and cellular redox status // Biochem. J.-1996.-313, pt 1.- P. 155-161.

19. Lo H. W., li-Osman F. Cyclic AMP mediated GSTP1 gene activation in tumor cells involves the interaction of activated CREB-1 with the GSTP1 CRE: a novel mechanism of cellular GSTP1 gene regulation // J. Cell. Biochem.-2002.-87, N 1.P. 103-116.

20. Manna P. R., Stocco D. M. Crosstalk of CREB and Fos/Jun on a single cis-element: transcriptional repression of the steroidogenic acute regulatory protein gene // J. Mol. Endocrinol.2007.-39, N 4.-P. 261-277.

21. Gottlicher M., Heck S., Herrlich P. Transcriptional crosstalk, the second mode of steroid hormone receptor action // J. Mol. Med.-1998.-76, N 7.-P. 480-489.

22. Marino M., Galluzzo P., Ascenzi P. Estrogen signaling multiple pathways to impact gene transcription // Curr. Genomics.-2006.-7, N 8.-P. 497-508.

УДК 577.152.28

Надійшла до редакції 23.03.09 